\title{
Macrofungi in community managed forest, Rupandehi district, Nepal: An ethnomycological study
}

\author{
Hari Prasad Aryal ${ }^{1^{*}}$, U. Budhathoki ${ }^{2}$ and R.D. Tiwari ${ }^{2}$

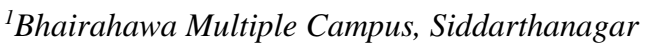 \\ ${ }^{2}$ Central Department of Botany, Kirtipur, Kathmandu \\ Tribhuvan University, Nepal \\ *Email: hahariprasadaryalo6@gmail.com
}

\begin{abstract}
This investigation explores the macrofungi with their identification and documentation of indigenous knowledge. The study area occupies 633 hector and lies within a narrow limit of altitude between 225 and $265 \mathrm{msl}$. The collected samples represented 31 species of Basidiomycetes belonging to 7 orders, 17 families and 22 genera. The dried specimens are deposited in the Tribhuvan University Central Department of Botany, Pathology Unit, Kathmandu, Nepal. The area embraces many mycophagous ethnic groups. The mycoelements prevailing in this area need sustainable development.
\end{abstract}

Kew words: Food value, local-medicines, macrofungal diversity, socioeconomy.

\section{Introduction}

Fungi are achlorophyllous heterotrophic organisms. They exhibit remarkable diversity in form, ranging from microscopic unicellular as in yeast to large macroscopic bodies as in Ascomycetes and Basidiomycetes. Macrofungi are the macroscopic fruiting bodies, known as mushrooms (Rinaldi \& Tyndalo, 1972).

Nepal is considered as the homeland for the mushroom floral diversity (Aryal et al., 2012). 817 mushroom species have been identified (Adhikari, 2009; Aryal \& Budhathoki, 2013abc; Aryal et al., 2014bc). 228 edible (Christensen et al., 2008), 66 poisonous (Pandey, 2008; Adhikari, 2009) and 88 medicinal species (Adhikari, 2009; Aryal \& Budhathoki, 2014a) have been reported. The investigation and study on mushrooms of Nepal started since $19^{\text {th }}$ century (Lloyd, 1808), since then several papers have been published and several botanical investigations have been done. Among these, very few reveal the studies and investigation on macrofungi from western Nepal. This area has not been previously investigated so far.

The study sites are rich in mushroom diversity and offer immense scope for ethnomycological studies. In spite of the fast modernization process, the local communities of this area still hold their traditional faith and depend on indigenous species for their various domestic needs and traditional medicines. The useful wild mushrooms and their ethno-information are being eroded as a result of degradation of appropriate habitat of the species, unsustainable land use activities and over-exploitation of natural resources.

\section{Study area}

The study area (Figure 1) is the southern belt of west Nepal and lies in Lumbini zone, Rupandehi district, Parroha VDC., W.N. 1,3,4,8 and 9. The total human population of the study area was 10146 (DDC, 2007.) with 2579 households (DFO, 2012). The vegetation in forest is dominated by members of the Dipterocarpaceae, Combretaceae and Leguminosae. Area of 
VDC is 48,960 hector of which $6,873.6$ hectare is covered by forest. This study area included 633 hector of forest, consists of sandy loam to loamy soil (DDC, 2007; DFO, 2012) and lies between $27.62851^{\circ}-27.69856^{\circ} \mathrm{N}$ latitude and $83.29716^{\circ}-83.36736^{\circ} \mathrm{E}$ longitude. The altitudinal range varies from $225-265 \mathrm{~m}$ asl and average annual rain fall is $1391 \mathrm{~mm}$ (GoN, 2010).

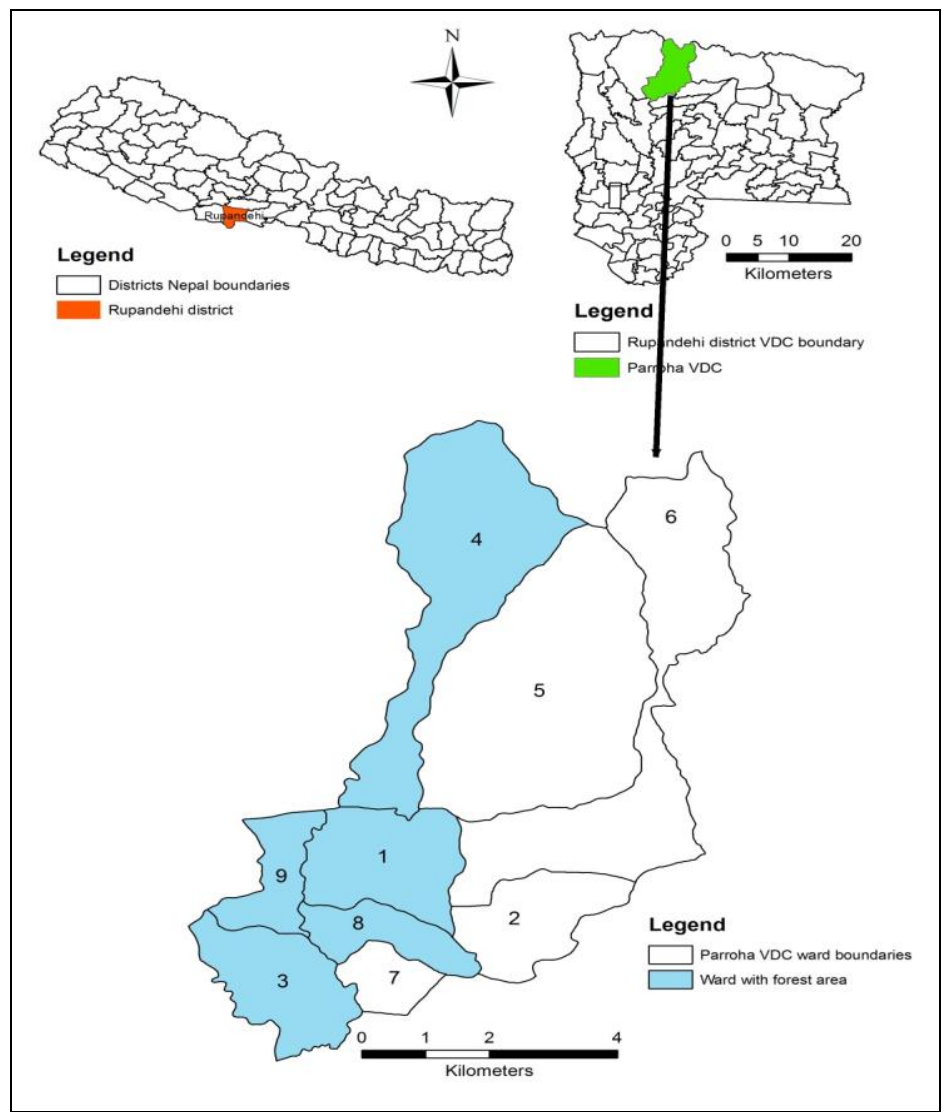

Figure 1. Sample collection sites.

\section{Materials and Methods}

Mushroom samples collection and interview with local informants were performed. Indigenous knowledge survey was done from $15^{\text {th }}$ to $31^{\text {st }}$ May and specimens were collected from $1^{\text {st }}$ June to $31^{\text {st }}$ Oct in 2011 and 2012. They will be randomly chosen by Random Block deign method (RBD) (Elliott, 1971). The Participatory Rural Appraisal (PRA) technique (Frendenberger, 2011) was done with local people aimed at getting information largely on nutritional aspects. Data was obtained by combined semi-structured questionnaire, participatory discussions and field observations.

Mushroom samples were photographed in their natural habitat and their morphological characters were noted. The samples were well dried and packed in wax paper bags with proper tag numbers. The habitat including ecological parameters viz. altitude, vegetation composition, soil type, soil $\mathrm{pH}$, soil moisture, humidity, and temperature were recorded. The frequency class was calculated by the formula: No. of Plots in which species ' $\mathrm{x}$ ' occurs $\times 100$

Total no. of plot 
The paper bags were brought to Central Department of Botany, Tribhuvan University, for further microscopic examination. The identification was done with the help of relevant literatures (Bakshi, 1971; Dickinson \& Lucas, 1979; Singer, 1986; Kumar et al., 1990) and on line data base such as: Biodiversity Library.org; Index Fungorum; Mycobank.org; tropicos.org).

\section{Results}

In the survey 31 species of Basidiomycetes from 7 orders belonging to 17 families and 22 genera were recorded with their brief descriptions.

Table 1. Wild mushroom species collected from Parroha community managed forest, Rupandehi District, Nepal

\begin{tabular}{|c|c|c|c|c|c|c|}
\hline SN & Scientific name & $\begin{array}{l}\text { Order } \\
\text { Family }\end{array}$ & Local name & Host/Substratum & Ecology & Application \\
\hline 1 & $\begin{array}{l}\text { Amanita caesarea (Scop.) } \\
\text { Pers. }\end{array}$ & $\begin{array}{l}\text { Agaricales } \\
\text { Amanitaceae }\end{array}$ & Suntale Chyau & Soil & Mycorrhizae & Used as vegetable \\
\hline 2 & $\begin{array}{l}\text { Amanita chepangiana } \\
\text { Tulloss \& Bhandary }\end{array}$ & $\begin{array}{l}\text { Agaricales } \\
\text { Plutaceae }\end{array}$ & $\begin{array}{l}\text { Salleu, Kukhura } \\
\text { phule chyau }\end{array}$ & Soil & Mycorrhizae & Used as vegetable \\
\hline 3 & $\begin{array}{l}\text { Amanita pantharina (D } \\
\text { C.) Kromb }\end{array}$ & $\begin{array}{l}\text { Agaricales } \\
\text { Amanitaceae }\end{array}$ & Bhut chyau & Soil & Mycorrhizae & Deadly poisonous \\
\hline 4 & Agaricus augustus Fr. & $\begin{array}{l}\text { Agaricales } \\
\text { Agaricaceae }\end{array}$ & Kaile Chyau & Soil & Saprophyte & Used as vegetable \\
\hline 5 & $\begin{array}{l}\text { Agaricus sylvicola } \\
\text { (Vittad.) Peck }\end{array}$ & $\begin{array}{l}\text { Agaricales } \\
\text { Plutaceae }\end{array}$ & Sal chyau & Soil & Saprophyte & not edible \\
\hline 6 & $\begin{array}{l}\text { Armellaria mella } \\
\text { (Vahl.:Fr.) Kummer }\end{array}$ & $\begin{array}{l}\text { Agaricales } \\
\text { Marasmiaceae }\end{array}$ & $\begin{array}{l}\text { Todke chyau, } \\
\text { Kale chyau } \\
\text { (shyamo) }\end{array}$ & $\begin{array}{l}\text { On decay log } \\
\text { from crevices in } \\
\text { moist shady place }\end{array}$ & Parasite & Edible, vegetable \\
\hline 7 & $\begin{array}{l}\text { Auricularia auricular- } \\
\text { judae (Bull.) Quel. }\end{array}$ & $\begin{array}{l}\text { Auriculariales } \\
\text { auriculariaceae }\end{array}$ & Kane chyau & $\begin{array}{l}\text { Log }(\text { Shorea } \\
\text { robusta })\end{array}$ & Saprophyte & $\begin{array}{l}\text { Edible, used to } \\
\text { prepared soup }\end{array}$ \\
\hline 8 & Bovista nigricans Pers. & $\begin{array}{l}\text { Agaricales } \\
\text { Lycoperdaceae }\end{array}$ & $\begin{array}{l}\text { Vakunde } \\
\text { Chyau }\end{array}$ & $\begin{array}{l}\text { Open grassland on } \\
\text { soil }\end{array}$ & Saprophyte & Inedible \\
\hline 9 & $\begin{array}{l}\text { Coltricia cinmmonea } \\
\text { (Pers.) Murrill }\end{array}$ & $\begin{array}{l}\text { Hymenochaetales } \\
\text { Hymenochaetaceae }\end{array}$ & $\begin{array}{l}\text { Mayur pankhen } \\
\text { Chyau }\end{array}$ & On leaf mould soil & Saprophyte & Inedible \\
\hline 10 & $\begin{array}{l}\text { Conocybe broneola } \\
\text { Kuhn. ex Kuhn. \& Watl. }\end{array}$ & $\begin{array}{l}\text { Agaricales } \\
\text { Bolbitiaceae }\end{array}$ & Tikka Chyau & $\begin{array}{l}\text { On tree trunks } \\
\text { stumps }\end{array}$ & Saprophyte & Inedible \\
\hline 11 & $\begin{array}{l}\text { Cpprinus Comatus (O.F. } \\
\text { Miill.)Pers }\end{array}$ & $\begin{array}{l}\text { Agaricales } \\
\text { Coprinaceae }\end{array}$ & Gobre Chyau & Soil & Saprophyte & $\begin{array}{l}\text { Edible at young, } \\
\text { dried powder with } \\
\text { rice/milk induced } \\
\text { sleep to child }\end{array}$ \\
\hline 12 & $\begin{array}{l}\text { Coprinus plicatilis } \\
\text { (Curtis) Fr. }\end{array}$ & $\begin{array}{l}\text { Agaricales } \\
\text { Coprinaceae }\end{array}$ & Payeje Chyau & $\begin{array}{l}\text { On } \log (\text { Acacea } \\
\text { catechu) }\end{array}$ & Saprophyte & Poisonous \\
\hline 13 & $\begin{array}{l}\text { Dacryopinax spathularia } \\
\text { (Schwein.) G.W. Martin }\end{array}$ & $\begin{array}{l}\text { Tramelles } \\
\text { Decrymycetaceae }\end{array}$ & Putali Chyau & $\begin{array}{l}\text { rotten wood } \\
\text { (Shorea robusta) }\end{array}$ & Saprophyte & not edible \\
\hline 14 & $\begin{array}{l}\text { Ganoderma lucidium P. } \\
\text { Karst. }\end{array}$ & $\begin{array}{l}\text { Polyporales } \\
\text { Ganodermataceae }\end{array}$ & Dadhu chyau & $\begin{array}{l}\text { Trunk }(\text { Bombax } \\
\text { ceiba) }\end{array}$ & Parasite & $\begin{array}{l}\text { Medicinal, remove } \\
\text { evil spirit, in } \\
\text { decoration. }\end{array}$ \\
\hline 15 & $\begin{array}{l}\text { Laetiporus sulphureus } \\
\text { Murrill }\end{array}$ & $\begin{array}{l}\text { Polyporales } \\
\text { Polyporaceae }\end{array}$ & $\begin{array}{l}\text { Kath-phule } \\
\text { chyau }\end{array}$ & $\begin{array}{l}\text { tree on forest } \\
\text { (Tectona grandis) }\end{array}$ & Parasite & $\begin{array}{l}\text { Young edible, used } \\
\text { for culinary purpose. }\end{array}$ \\
\hline 16 & $\begin{array}{l}\text { Leucopaxillus giganteus } \\
\text { Boursier }\end{array}$ & $\begin{array}{l}\text { Agaricales } \\
\text { Tricholomataceae }\end{array}$ & Soli Chyau & open grassland & Saprophyte & $\begin{array}{l}\text { Edible, but not } \\
\text { popularly used. }\end{array}$ \\
\hline 17 & $\begin{array}{l}\text { Macrolepiota fuliginosa } \\
\text { (Barla) Bon. }\end{array}$ & $\begin{array}{l}\text { Agaricales } \\
\text { Agaricaceae }\end{array}$ & Gobbre chyau & soil & Saprophyte & used as vegetable. \\
\hline 18 & $\begin{array}{l}\text { Macrolepiota rhacodes } \\
\text { (Vittad.) Sing }\end{array}$ & $\begin{array}{l}\text { Agaricales } \\
\text { Agaricaceae }\end{array}$ & Gobbre chyau & soil & Saprophyte & $\begin{array}{l}\text { Edible, used as } \\
\text { vegetable. }\end{array}$ \\
\hline 19 & $\begin{array}{l}\text { Marasmius oreade (Bolt.) } \\
\text { Fr. }\end{array}$ & $\begin{array}{l}\text { Agaricales } \\
\text { Marasmiaceae }\end{array}$ & Kanike Chyau & soil & Saprophyte & $\begin{array}{l}\text { Edible but not } \\
\text { popularly used. }\end{array}$ \\
\hline 20 & $\begin{array}{l}\text { Psathyrella candolleana } \\
\text { (Fr.) Quel. }\end{array}$ & $\begin{array}{l}\text { Agaricales } \\
\text { Coprinaceae }\end{array}$ & $\begin{array}{l}\text { Kirkounle } \\
\text { Chyau }\end{array}$ & $\begin{array}{l}\text { Log (Dalbergia } \\
\text { latifoliya })\end{array}$ & Saprophyte & Inedible. \\
\hline 21 & $\begin{array}{l}\text { Pycnoporus cinnabarinus } \\
\text { (Jacq.) P. Karst. }\end{array}$ & \begin{tabular}{|l|} 
Polyporales \\
Polyporaceae
\end{tabular} & Sindure chyau & $\begin{array}{l}\text { Stump (Syzygium } \\
\text { cumini) }\end{array}$ & Saprophyte & $\begin{array}{l}\text { Medicine, for relief } \\
\text { ear pain, Mumps }\end{array}$ \\
\hline
\end{tabular}




\begin{tabular}{|c|c|c|c|c|c|c|}
\hline 22 & $\begin{array}{l}\text { Russula emetica } \\
\text { (Schaeff.) Pers. }\end{array}$ & $\begin{array}{l}\text { Russulales } \\
\text { Russulaceae }\end{array}$ & Ratteyou & litter & Mycorrhizae & $\begin{array}{l}\text { Poisonous Medicine } \\
\text { that cause vomiting, }\end{array}$ \\
\hline 23 & Russula foetens Pers. & \begin{tabular}{|l|} 
Russulales \\
Russulaceae
\end{tabular} & Gandhe chyau & Soil & Mycorrhizae & Poisonous \\
\hline 24 & Russula nigricans Fr. & \begin{tabular}{|l|} 
Russulales \\
Russulaceae
\end{tabular} & Handi chyau & Soil & Mycorrhizae & Edible, pickle \\
\hline 25 & $\begin{array}{l}\text { Schizophyllum commune } \\
\text { Fr.: Fr. }\end{array}$ & \begin{tabular}{|l} 
Agaricales \\
Schizophyllaceae
\end{tabular} & Pankha chyau & $\begin{array}{l}\text { decayed wood: } \\
\text { Shorea robusta }\end{array}$ & Saprophyte & $\begin{array}{l}\text { Edible, Religious, } \\
\text { cultural Culinary }\end{array}$ \\
\hline 26 & Scleroderma bovista Fr. & $\begin{array}{l}\text { Bolatales } \\
\text { Sclerodermataceae }\end{array}$ & Alu chyau & Soil & Mycorrhizae & $\begin{array}{l}\text { vegetable } \\
\text { Edible/Medicinal }\end{array}$ \\
\hline 27 & $\begin{array}{l}\text { Scleroderma citrinum } \\
\text { Pers. }\end{array}$ & $\begin{array}{l}\text { Bolatales } \\
\text { Sclerodermataceae }\end{array}$ & Dalle chyau & Soil & Mycorrhizae & $\begin{array}{l}\text { Inedible/Medicinal; } \\
\text { causes gastric or } \\
\text { acute indigestion. }\end{array}$ \\
\hline 28 & $\begin{array}{l}\text { Sparasis crispa (Wulfen.) } \\
\text { Fr. }\end{array}$ & \begin{tabular}{|l|}
$\begin{array}{l}\text { Polyporales } \\
\text { sparadiaceae }\end{array}$ \\
\end{tabular} & Cauli chyau & $\begin{array}{l}\text { Log (Tectona } \\
\text { grandis) }\end{array}$ & Parasite & Edible, used as soup. \\
\hline 29 & $\begin{array}{l}\text { Termitomyces clypeatus } \\
\text { R. Heim. }\end{array}$ & \begin{tabular}{|l|} 
Agaricales \\
Tricholomataceae
\end{tabular} & Dhamere chyau & Termites nest & $\begin{array}{l}\begin{array}{l}\text { Obligate } \\
\text { sumbiont }\end{array} \\
\end{array}$ & \begin{tabular}{|l|} 
Edible, Medicinal, \\
Feaver. Miseales \\
\end{tabular} \\
\hline 30 & $\begin{array}{l}\text { Termitomyces eurrhizus } \\
\text { (Berk.) Heim. }\end{array}$ & $\begin{array}{l}\text { Agaricales } \\
\text { Tricholomataceae }\end{array}$ & Dhamere chyau & Termites nest & $\begin{array}{l}\text { Obligate } \\
\text { sumbiont }\end{array}$ & $\begin{array}{l}\text { Edible, Medicinal, } \\
\text { Fever, Miseales, used } \\
\text { mixed with herbs as a } \\
\text { lotion in skin diseases }\end{array}$ \\
\hline 31 & $\begin{array}{l}\text { Volvorella volvecea } \\
\text { (Bull.:Fr.) Sing. }\end{array}$ & $\begin{array}{l}\text { Agaricales } \\
\text { Plutaceae }\end{array}$ & $\begin{array}{l}\text { Kathemuse } \\
\text { chyau }\end{array}$ & $\begin{array}{l}\text { On wood (Adena } \\
\text { cardifolia) }\end{array}$ & Saprophyte & $\begin{array}{l}\text { Edible. Excellent. } \\
\text { Used as vegetable }\end{array}$ \\
\hline
\end{tabular}

$($ Col. No. $=$ Sample collection Number $)$

A notable frequency of Amanita caesarea, A. chepangiana, A. pantherina, Agaricus augustus, A. sylvicola, Coprinus comatus, C. plicatilis, Macrolepiota fuliginosa, M. rhacodes, Russula emetica, $R$. foetens, $R$. nigricans, Scleroderma bovista, S. citrinum, Termitomyces clypeatus, and $T$. eurhizeus, were observed. Out of the total collection $61 \%$ mushrooms fall under Agaricales followed by, Polyporales, Russulales, Boletales, Auriculariales, Hymenochaetales and Tremellales.

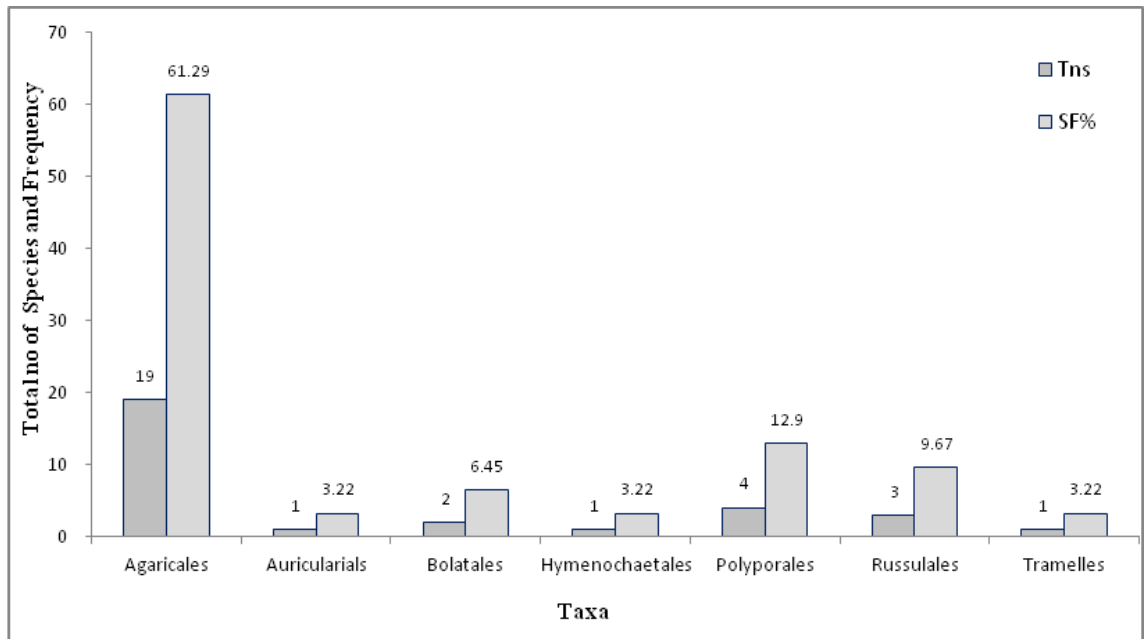

Figure 2. Showing the total No. of species (Tns) and \% of frequency of groups (SF \%) of Basidiomycotina.

Indigenous knowledge and therapeutic use

On the basis of information collected, $98 \%$ of the collected mushrooms are used as food, $2 \%$ as medicine. The consumption data reveals that mushrooms are maximum used as food by $55 \%$ women, followed by $30 \%$ children and $15 \%$ men. People use these mushroom for the remedy of 
different types of diseases and ailments. Out of 200 respondents, $42 \%$ people use it for the remedy of measles, $25 \%$ yellow fever, $15 \%$ jaundice, $6 \%$ in appetence, $5 \%$ constipation, $4 \%$ stomach pain, $1.5 \%$ muscular pain, $1 \%$ skin diseases and $0.5 \%$ for mumps, ear pain, cut wounds etc.

\section{Discussion}

Macrofungi found in this area are not only an important source of food but also use them for medicinal purpose by the local people. The present study revealed that there are plenty of edible species. The most common among them are collected, sacked in bags and carried to market for selling (e.g. Scleroderma bovista, Termitomyces clypeatus, T. eurrhizus and Volvorella bombaycina etc).

Among the 31 collected taxa, 17 are edible, 6 Inedible, 4 poisonous, 3 medicinal and 1 has religious value. Some of the the edible species viz. Scleroderma bovista and different species of Termitomyces are also used for medicinal purpose (Aryal \& Budhathoki, 2013d; 2014a). The medicinally important tropical polypore like Pycnoporus cinnabarinusis is used for the remedy of infectious disease (Mump), Ear pain etc. Scleroderma citrinum the medicinal species is also used as food. The cosmopolitan inedible species Schizophyllum commune is sometimes used for culinary purposes in food deficit condition. This species has religious value also and is used as 'Sagun' for better happening in the Marriage ceremony in Newar community (Aryal \& Budhathoki, 2013d).

During surveys, it was found that the population of Macrolepiota fuliginosa, Russula nigricans, Termitomyces clypeatus, T. eurhizeus and Volvariella bombycina is declining since the last two decades due to deterioration of forest. Amanita caesarea, A. chepangiana, A. fulva, A. pantherina, Agaricus augustus, A. sylvicola, Coprinus comatus, C. plicatilis, Scleroderma bovista, S. citrinum, Termitomyces clypeatus and T. eurrhizus were found in abundance during sample collection. Being saprophytic, obligatory symbionts as well as part of the mycorrhizal association, these macro fungi play an important role for increase the soil fertility in the forest by biodegradation as well as decomposition of the lignocelluloses compounds of leaf litter. The litter debris of vascular flora favors the regulation and maintenance of temperature and moisture in the soil for these macrofungi. The toxic species listed are Amanita pantherina, Coprinus plicatilis, Russula emetica and $R$. foetens.

\section{Conclusion}

The reported mushrooms are widely spread throughout the country in tropical to temperate belts. It needs extensive investigation to find out their species richness, distribution pattern, species diversity and ethnomycological uses. Some of the important macrofungi (Scleroderma, Termitomyces, Volvorella spp.), need special attention to be conserved against the threat to avoid their unmanaged and unscientific exploitation. Harvesting should be done more scientifically rather than using traditional methods. The mycoelements prevailing in this area need sustainable conservation and utilization.

\section{Acknowledgements}

The authors would like to acknowledge Nepal Academy of Science and Technology for providing research grant to conduct this study. The authors are obliged to the Central Department of Botany, Tribhuvan University for providing laboratory facilities. Thanks to the Institute of Agriculture and Animal Science for granting my study leave during this study 
period. Further, the authors would like to appreciate Dr. M.K. Adhikari for his cordial support. Last but not least, sincere thanks are extended to the local people of the study area for providing information to the authors.

\section{References}

Adhikari, M.K. 2009. Researches on the Nepalese mycoflora. Adhikari, K.S., Alka Basti Marga, Kathmandu, Nepal. 82 p.

Aryal, H. P. and Budhathoki, U. 2014a. Ethnomycology of Termitomyces spp. R. Heim for its medicinal importance in Nepal. An International Journal of Medicinal Plants. New Delhi, India. 6(2): 128137.

Aryal, H.P. and U. Budhathoki. 2013a. Buchwaldoboletus lignicola (Basidiomycetes), an Inedible Wild Mushroom New to Nepal. Our Nature. 11(1): 31-35. http://dx.doi.org/10.3126/on.v11i1.8241

Aryal, H.P. and U. Budhathoki. 2013b. The Genus Amanita (Pers.) in Lumbini zone, Nepal. Scientific World. 11(11): 113-120. http://dx.doi.org/10.3126/sw.v11i11.8564

Aryal, H.P. and U. Budhathoki. 2013c. Termitomyces albuminosus (Berk.) Heim a New Fungal Record from Arghakhnchi, Nepal. OAKS. 9: 44-47.

Aryal, H.P. and U. Budhathoki. 2013d. Mycodiversity at Sankarnagar Community Forest, Rupandehi District. Nepal Journal of Science and Technology. June, 2013d. 14 (1): 75-80. http://dx.doi.org/ 10.3126/njst.v14i1.8925

Aryal, H.P., Budhathoki, U. and Adhikari, M.K. 2012. Mycodiversity in Peepaldanda Community Forest, Western Terai Region of Nepal. Bull Dept. Pl. Res.34: 13-17.

Aryal, H.P., R. Poudel and U. Budhathoki. 2014c. Macrofungi from Siddhababa Sacred Grove: west Nepal. The Journal of Agriculture and Environment. Ministry of Agriculture and Cooperatives, Simhadarbar, Kathmandu. Government of Nepal. 15: 107-116. www.journal of agriculture and environment nepal.com

Aryal, H.P., U. Budhathoki and R.D. Tiwari. 2014b. Termitomyces microcarpus (Berk. \& broome) R. Heim: A New records from Nepal. Jour. Mycol. Pl. Pathol. 44(1): 13-18.

Bakshi B.K. 1971. Indian Polyporaceae. Indian Council of Agriculture Resources, New Delhi.

Christensen, M., Bhattarai S., Devkota S. and Larsen H.O. 2008. Collection and use of wild edible fungi in Nepal. Eco. Bot. 62 (1): 12-23. http://dx.doi.org/10.1007/s12231-007-9000-9

DDC. 2007. Rupandehi, District Profile.

DFO. 2012. District Forest Office, Rupandehi: Brief Introduction and Progress Report.

Dickinson, C. and Lucas, J. 1979. Encyclopedia of Mushrooms. Orchid Publication, London.

Elliott, J. M., 1971. Some methods for the statistical analysis of samples of benthic invertebrates. Sci. Publ. 25. Freshwater Biol. Ass., Ambleside, Westmorland.

Freudenberg, K. S., 2011. A Manual for CRS Field Workers and Partner. Maryland, USA.

GoN (Government of Nepal). 2010. Climatological and agro meteorological records of Nepal. Government of Nepal. Ministry of Environment, Science and Technology, Department of Hydrology and Meteorology, Kathmandu, Nepal.

Kumar A., Bhatt R.P and Lakhanpal T.N. 1990. The Amanitaceae of India. Dehradun, India: Bishen Sing Mahendra Pal Singh. 160 pp.

Lloyd, C.G.1808. Mycological notes. Mycology. Cincinnati, Ohio: Lloyd Library \& Museum Pp.1-75.

Pandey, N. 2008. Mushroom Diversity in central Nepal: An ethnomycological Approach. Ph.D. Thesis, Central Department of Botany, Tribhuvan University, Nepal.

Rinaldi, A. and Tyndalo, V. 1972. The Complete Book of Mushrooms. Cresent book, New York.

Singer, R. 1986. The Agaricales in modern taxonomy (4 ${ }^{\text {th }}$ edition), Bishen Singh Mahendra Pal Singh, Dehradun (India). 981p. 